\title{
Transience in Four Old English Elegies
}

\author{
Irina Rau
}

\section{Introduction}

To many of us, it oftentimes feels as if the years and our time on earth fly us by. In his Ecclesiastical History of the English People, dating from the early 8th century, the Venerable Bede brings immediacy to this image by picturing a sparrow whose swift flight through a hall represents the ephemeral nature of human life. An unnamed counsellor of King Edwin asks him to imagine how

adueniens unus passerum domum citissime peruolauerit; qui cum per unum ostium ingrediens mox per aliud exierit, ipso quidem tempore quo intus est hiemis tempestate non tangitur, sed tamen paruissimo spatio serenitatis ad momentum excurso, mox de hieme in hiemem regrediens ... ${ }^{1}$

(II.13, p. 184)

The motif of transience, likewise found in Old English elegies surviving in the late tenth-century Exeter Book, parallels Bede's simile of the sparrow. The Wanderer, The Seafarer, Deor, and The Ruin all share the notion of a transient earthly life and together allow us to study different portrayals of transience. ${ }^{2}$ It is noticeable that earthly transience manifests itself in the momentary forces of nature, in decaying

\footnotetext{
${ }^{1}$ Ed. Colgrave and Mynors. "Arriving, one of the sparrows were to fly swiftly through the house; which, entering by one door, were to exit by another soon; during the time it is inside, it is certainly not affected by the storm of the winter, but with the very short time of peace having run out, it soon flies from one winter into another." Unless indicated otherwise, all translations are my own.

2 References to these four elegies follow the edition by Bjork throughout.
} 
architecture, and in temporary human hardship. Accordingly, these aspects constitute the outline of the argumentation in order to support the thesis that these four elegies reinforce the contrast between life in the transient world and heavenly eternity. At least The $W$ anderer and The Seafarer share the Christian undertone suggesting that eternity and stability inhere in God and in heaven after death.

Etymologically, transience derives from Latin terms. Transitio is the feminine noun and describes an "(act of) crossing, passage," "transition," "change," or "transformation." The masculine noun transitus holds similar meanings: "(act of) crossing (over from one place to another)," "passage," "ceasing to be," (i.e. dying) and the "elapsing (of time)." Its adjective transitorius signifies "of or pertaining to passage across from one place to another," "passing," and "(esp. of worldly things) transient, fleeting," "temporary" (Howlett s.vv. transitio, transitorius, transitus). In the Old English language, feallendlic and lane carry similar meanings. Feallendlic means perishable, transitory, and frail, and lane signifies that something is granted for a time only, impermanent, transitory, and temporary (BosworthToller s.vv. feallend-lic, láne). The $W$ anderer-poet particularly uses lane to define the quality of earthly goods and human relationships in lines 108-10. Christine Fell stresses the dichotomy of lane, emblematising a journey, and ece, which signifies eternal, perpetual, and everlasting, and is associated with eternal life in the next world (181).

This opposition between the transient world and heavenly eternity dominates (whether or not explicitly) at least The $W$ anderer and The Seafarer, whereas views of an almighty Lord or the rule of fate prevail in all four elegies. Their literary classification as elegies requires reconsideration in the way that they cannot be grasped in the classical sense as lengthy songs of lament and melancholy written in elegiac couplets. Klinck affirms an influence, that is a "parallel between ... the Latin genre" and the Old English form although the latter "had other roots" $(7,11)$. Occurrences of Christian ideas and Latin patterns are intrinsic to many of the Old English elegies (Orchard, "Not What It Was" 102), which share, alongside transience, themes such as "loss, suffering and morality" (Fell 108). Except for The Ruin, the other three poems include a speaker referring to himself as " $\mathrm{I}$ " who realises that the once joyous life has gone and that he is left alone without purpose and companions. Their authors use both natural, architectural, and emotional imagery to confirm the sublimity of both fate and divine eternity in a transient world. The following sections, whose topics cohere and intertwine, provide a thorough analysis of the motif of transience surfacing in the description of earthly things: seasons, architecture, treasures, and human suffering. 


\section{Transience in Four Old English Elegies}

\section{The Transient Nature of Elemental Forces}

Seasonal imagery is intrinsic to the elegies. Certainly, the cold seasons with their different appearances and forms of precipitation symbolise transient earthly hardship and are thus inseparable from the third subsection of the main part addressing human suffering. As exiles, both Wanderer and Seafarer are troubled by tempestuous weather and stormy seas during their journeys. The climate in The Ruin is similarly relentless and causes the once solid architecture to decay. Depictions of wintery atmospheres and cold emotions provide the setting and serve to introduce this topic: the "hrim-cealde sæ" ("frosty cold sea," Wanderer 4) is a hardship for the Wanderer, challenging him on his watery path of exile. As if it was not hard enough to travel all on one's own, the weather on the ice-cold sea where "hrim ond snaw, hagle gemenged" ("rime and snow, mingled with hail," 48) fall ceaselessly intensifies his grim mood. The Seafarer's mental and physical condition resembles the Wanderer's mood. A frosty cold governs the former by fettering his feet and body with icicles, his perception of "hlimman sæ, / is-caldne wæg" "the sea roaring, the ice-cold wave," Seafarer 18-19) ${ }^{3}$ gives shape to his wintery surroundings. Stanley B. Greenfield points out that winter allegorises human sinfulness on earth. Indeed, The Seafarer warns against being sinful and praising earthly relationships and treasures (Greenfield 208). In Deor, Welund's fate shares the wintery tone insofar as his exile is winter-ceald ("winter-cold," 4). In the four elegies, storms most notably ravage the earth and display its vanity. This manifests itself in the destruction of walls, halls, and buildings. The winds and storms have overthrown them and govern nature as well as humanity inasmuch as "pas stan-hleopu stormas cnyssað, / hrið hreosende hrusan bindeð" 4 as depicted in The Wanderer, and "stormas pær stan-clifu beotan" ("there storms beat the rocky cliffs," 23) in The Seafarer. It is the same case with hail which both Wanderer and Seafarer encounter in the form of heavy showers: "hægl-fare hælepum on andan" ("a hailstorm against men in malice," The Wanderer 105) and "hægl scurum fleag" ("hail flew in showers," Seafarer 17).

Whether the author deliberately used the Old English verb fleogan here in connection to hail remains a question of interpretation. However, it perfectly heralds the start of the passage in The Seafarer that features a band of six birds such as wild swan, gannet, or seagull which "become surrogates for his former human companions" (Klein 120). Similarly, the Wanderer beholds a group of "bapian brimfuglas" ("seabirds bathing," Wanderer 47$)^{5}$ while dwelling on the memory of his dead kinsmen. This memory fades as quickly as the spoken words of the birds,

\footnotetext{
${ }^{3}$ See also ll. 8-9, 17.

4 "These storms beat the stone-slopes, the falling storm binds the ground," 101-02.

${ }^{5}$ See also Seafarer $19-24$.
} 
making both metaphors of earthly ephemerality (Irvine 131-32). While the birds' language and sounds are alien to the Wanderer, the Seafarer knows what the sorrowful voice of the cuckoo indicates. Although the bird represents "sumeres weard" ("summer's guard," Seafarer 54) and is accordingly regarded as a joyous creature, his singing "sorge beodeð / bitter in breost-hord" ("summons sorrow, bitter in the heart," 54-55). Pheifer concisely summarises the cuckoo's ambivalent associations in his approach to lines 53-55 of The Seafarer, which compare the bird's joyful function as "the messenger of spring" with its occasional appearance in "Slavic and Celtic folk-lore ... [as] a harbinger of sorrow and death" (282). Its ambiguity parallels the concept of the sea voyage which can signify both "attraction and hardship" (283). The cuckoo's sad song can be interpreted as an audible sign of transience: time passes with the circular change of the seasons and nothing lasts forever. The theme of transience displayed by birds likewise surfaces in the term of the fleotendran ("floating ones," 54) in The Wanderer. While "the floating ones" refers to the group of bathing seabirds, it can also stand as a metaphor for the souls of the dead kinsmen the Wanderer remembers while looking at the sea. The memory of them passes through his mind as swiftly as the seabirds swim past him and deprive him of any companionship.

To return to the storms, the "atol ypa gewealc" ("the horrid tossing of the waves," Seafarer 6$)^{6}$ already suggests that the tempestuous forces of nature trouble the Seafarer's voyage. He experiences that "norpan sniwde; / hrim hrusan bond; hægl feol on eorpan, / corna caldast" - three forces which make the waves roll and subjugate the world both metaphorically and literally. Particularly in The Ruin, it is visible how storms devastate whole cities and leave ruins behind. Not only "hrim on lime" ("frost on the mortar," 4) but also heavy storms have either shattered the buildings or attempted to damage them: "scearde scur-beorge scorene, gedrorene" and "ofstonden under stormum."8 One can easily associate storms with transience since they are temporary conditions of the weather belonging to the colder seasons of autumn and winter. Just like Bede's sparrow, the human being lives on from storm to storm, from winter to winter, and thus from year to year. The warm hall in his simile, typifying a "comfortable haven against the cold and uncertainty of what goes before and of what comes after ..., encourages the [attentive audience] to embrace Christianity in the hope that ... there will be a further haven" after death (Toswell 8). The sparrow is emblematic of "the human soul" that can select a "life of comfort and security in the [heavenly] hall" (8).

Where there are storms, there is typically also darkness. At a moment's notice, darkness comes and goes and oftentimes accompanies the wintery storms. The Wanderer recognises "wintres woma, ponne won cymeð" ("the noise of the winter, then darkness comes," 103) which makes it reasonable to conclude that winter

\footnotetext{
${ }^{6}$ See also 1l. 35, 46.

7 "It snowed from the north; frost bound the earth; hail fell on the earth, the coldest of grains," 31-33.

8 "The gaping shelters against storm are torn, have fallen," 5; "remained standing under storms," 11.
} 
announces and implicates darkness. The poet creates a strong mental image when he contrasts the bright friend of gold, that is the lordly treasure giver, with the dark soil that covers him after his death: "gold-wine minne / hrusan heolstre biwrah" ("the darkness of the ground covered my gold-friend," 22-23). Heart and life can become dark as well as lines 59 and 89 reveal: "mod-sefa min ... gesweorce" ("my heart ... grow dark") and "pis deorce lif" ("this dark life") express the Wanderer's grief and desperation. His "earthly life implicitly contrast[s] with the heavenly one, where there is eternal light" (Bately 7), and his mood matches the dark atmosphere that winter creates. Deor contains a passage that parallels this one: an individual suffering from sorrow "on sefan sweorceð" ("darkens in the mind," 29) and feels as if he would never experience any joy of life again.

Concerning the aspect of subjugation of the earth, the force of darkness is qualified as a helmet that lies on the ground like a heavy cover: "hu seo prag gewat, / genap under niht-helm, swa heo no wære!"9 This description illustrates the transience of time by using the colour black, which suggests that the time that has passed was once bright and joyful. Furthermore, it seems as if time can easily be extinguished like a flame, leaving nothing but darkness as a reminder of its momentary nature. In addition, darkness and night symbolise evil and allude to the devil in a Christian context. Abandoning the land means abandoning darkness and human sinfulness, striving for the light of heaven (Holton 210). Both Wanderer and Seafarer encounter the "niht-scua" that "nipeð" ("the night shadow grows dark," Wanderer 104) or "nap" ("grew dark," Seafarer 31) and strikingly, darkness precedes and announces showers of hail and snow from the north in both cases. The corresponding use of both register and structure as it is observable in these two elegies is remarkable. Although Deor and The Ruin include a few references to the natural forces, they are more prominent in The $W$ anderer and The Seafarer. All four elegies share frosty atmospheres and landscapes where sorrowful individuals and exiles-if there are any survivors at all-are bereft of any joy. Severe winters, storms, and darkness surround them and reflect their mood. When minds and hearts darken, their owners metaphorically lose their lives and become mindful of their limited time on earth.

\section{Ancient enta geweorc in Ruins}

Following the above analysis of the rapid change of the seasons and the forces of storms against the background of transience in nature, this subsection will be more concerned with the transience of architecture. Unlike nature, architecture is created by human hands; it is the material result of human ideas. As the elegies exhibit, time, heavy storms, and warfare could damage these "concrete" ideas expressed by the set phrase of the "work of giants." Appearing in The Wanderer

\footnotetext{
9 "How the time departed, darkened under the night helmet, as if it had not been!"; Wanderer 95-96.
} 
("eald enta geweorc idlu stodon," "the old work of giants stood empty," 87) and in The Ruin ("brosnað enta geweorc," "the work of giants decays," 2), it testifies to the fact that the monumental stone buildings could not withstand the effects of time and militant attacks. Less explicitly, the "or-ponc ærsceaft" ("skilful ancient work," Ruin 16) praises the skills and creations of ancient master builders and expresses admiration for antiquity. Enta geweorc connotes "an awed regard for Roman ruins, considered to be the products of a technologically superior culture" (Anderson 69). ${ }^{10}$ However, these lines reveal the vanishing of ancient architecture and their cultures along with it. The decay of buildings immediately implies how rapidly and easily societies and kingdoms are replaceable by others.

Highly detailed descriptions of cities, walls, buildings, and halls accompany the enta geweorc throughout the entire poem. As it "reads like a description of an actual site," some scholars concluded that it pictures Bath, once occupied by the Romans (Klinck 61). In fact, The Ruin survives incomplete and among many others, Andy Orchard qualified the text's condition as "a ruin, scarred by a diagonal burn that affects no fewer than twelve of the thirty-six surviving manuscript lines" ("Reconstructing" 45). The first twelve lines of The Ruin dismember the city in its parts which equally reflects the text's ruinous state:

Wrætlic is pes weal-stan, wyrde gebræcon;

burg-stede burston, ...

Hrofas sind gehrorene, hreorge torras,

hring-geat berofen. $(1-4)^{11}$

The picture of decay and devastation continues:

Oft pæs wag gebad

ræg-har ond read-fah rice æfter oprum,

ofstonden under stormum; steap geap gedreas.

Worað giet se weall-steall wæpnum geheapen;

fel on foldan forð-gesceaft bærst

grimme gegrunden. $(9-14)^{12}$

The passage illustrates how enduring the city had been before it finally surrendered to the attacks of time, weather, and war. The following lines in The Wanderer echo the image of tottering walls and buildings: "winde biwaune weallas stondap /

\footnotetext{
10 See also p. 70, in which Anderson associates the wires and rings being parts of the architectural constructions with connectors in a society, and p. 80.

11 "Wondrous is this wall stone, broken by fate; the city has broken apart ... Roofs are fallen, towers ruinous, the ring gate is bereaved (i.e. destroyed)."

12 "Often this wall survived, grey with lichen and red-stained, one kingdom after another, remained standing under storms; towering, curved, it decayed. The wall place still totters, hewn by weapons; it fell to the earth, its future condition burst, grimly ground down."
} 
hrime bihrorene, hryðge pa ederas. / Weorniað pa win-salo"; 13 the whole dwelling-place is left in devastation. Subsequent lines of The Ruin picture the ancient city with its "burg-ræced, burn-sele monige, / heah horn-gestreon, ... meodoheall monig"14 and even further "wig-steal" ("bastion," 27), "hofu" ("houses," 29), "bapu" ("baths," with a wall encircling them, 40), "ond pæs teafor-geapa tigelum sceadeð / hrost-beages hrof." 15 While the mead-halls allude to Germanic culture, the bath-houses repeatedly mentioned represent Roman culture and customs and thus revisit the notion of the enta geweorc. The use of the past tense is noticeable throughout the poem and foreshadows the contrast between the city that was once bright, full of life and human joys, and the remaining ruins now standing in a wasteland. Janet Bately studied the role of time and use of tenses in The Ruin, The Seafarer, The Wanderer, and The Wife's Lament. She concluded that the four elegies share the links between past, present, and future to the extent that shifts between past and present tenses reflect experiences such as passages approaching the $u b i$ sunt topos, present suffering, dreaming, future divine consolation, and eternity (34, 13-14). Accordingly, approximately the first third of The Ruin is written in the present tense, whereas the description of the city's vivid and joyful past dominates the remainder. The majority of verbs denote decay and collapse. Stone walls and buildings moulder, decay, fall, burst, totter, or collapse and the half-line reading "forweorone, geleorene" ("decayed, departed," 7) indicates that the inhabitants have died with their city. The "stan-hofu stodan" ("the stone houses stood," 38) once solid and impressive, the grey stone buildings and the wide kingdom even possessed a "bright" splendour but lay in ruins on the earthly ground now. ${ }^{16}$

The ground has its peculiarities. It seems as if the ground has its independent existence insofar as it is personified and plays a minor part in The Ruin, The Wanderer, and The Seafarer. At first, the ground appears as a grave that keeps the bodies of the master architects in a figurative tight grip, as in "eorð-grap hafað / waldend wyrhtan ... / heard-gripe hrusan." 17 It also serves as a hiding place both for the dead one ("eorð-scræfe," "in the earth-cavern, i.e. grave," Wanderer 84) and for his hoard of gold ("græf wille golde stregan / bropor his geborenum"18). In addition to its tight grip, the dark ground also "swallows," as if it possessed a great mouth that devours living beings and cities alike: "grund eall forswealg" ("the ground devoured all," Ruin 14). Similarly, the crusts of clay are qualified to be so strong as to bend and deform the works of concrete ("lam-rindum gebeag," 17). In contrast to architecture, the earth protrudes as an all-absorbing force to which no earthly creation can do any damage. Besides its transient character immanent in

\footnotetext{
13 "Walls stand blown by the wind, covered with frost, the houses shaken by storms. The wine halls fade away," 76-78.

14 "City dwellings, many bath-houses, an abundance of high pinnacles, ... many mead-halls," 21-23.

15 "And the woodwork of the red curved roof sheds its tiles," 30-31.

16 Lines 21, 37, and 40 praise how "beorht," "bright" the city once had been.

17 "Earth's grasp holds the almighty architects ... the hard grip of the earth," The Ruin 6-8.

18 "The brother wants to strew the grave with gold for his brother," Seafarer 97-98.
} 
this imagery, the devouring of the earth likewise presages its capability of selfdestruction.

However, counter-images occur that are less dark and forlorn. The concluding passage of The $W$ anderer praises the heavenly Father in whose kingdom the believers expect consolation. This promise conveys the notion that stability is absent from the buildings of stone the supposed giants had attempted to build for eternity, but rests in the heavens where the almighty Lord rules (The Wanderer 115). Evidently no one is able to imitate the divine architecture which stands the test of time. Indeed, it is, being ece, built for eternity and not located on lane earth but in heaven. This search for consolation and a safe haven appeals to the Seafarer. He is a solitary voyager who has abandoned civilisation for the sake of salvation. To him, the endless sea is the path to the eternal heaven where he finds comfort (Holton 213, 215, 217). This even gets to the point where the Seafarer proposes "uton we hycgan hwær we ham agen, / ond ponne gepencan hu we pider cumen." 19 Clearly, he does not think of his home as an earthly location, otherwise he would not have left it. He rather considers it to be in heaven with God, which makes him a Christian exile (Holton 209, Irvine 132). With the seasons alternating and spring leaving its visible traces on earth, "byrig fægriað / wongas wlitigað, woruld onetted," 20 and the transience of earthly beauty and time are recalled to the mind. This image of transience differs from the one portrayed in The Ruin. The former is positive and addresses spring and the awakening spirits of nature, while the latter draws the picture of a decaying city whose parts have fallen to the ground and have been swallowed by it. The brickwork of buildings, once interrelated and cohesive through mortar, has broken apart in The Ruin. Every brick can represent an inhabitant of the city and similarly, every wall can represent a human creation. In this sense, one can conceive of the ruinous city as a past society or human culture that has, with all its joys, feasts, and companionships, fallen under the mighty rule of time. By beholding the ruins, human generations are warned not to cherish earthly things beyond measure since they will fade as the masonry has. Accordingly, architecture as an aspect of transience functions as a lesson in prudence.

\section{Ephemeral Earthly Gifts and Human Hardship}

Worldly riches and human suffering equally recur and interrelate as images of transience. The elegies portray fate and God as the ruling forces either providing individuals with treasures and honour or inflicting misery on them. Deprivation of gifts can be the cause of human hardship. For valiant warriors, the mead-halls

\footnotetext{
19 "Let us think where we have our home, and then think how we can get there," Seafarer 117-18.

20 "The city becomes fair, the plains grow beautiful, the world moves rapidly," Seafarer 48-49.
} 
("meodo-heall monig monn-dreama full"'21) are the centre of human joys, feasting, boasting, and host the company of lords and their retainers. In these halls, they receive their treasures which are specified thus: a warrior "seah on sinc, on sylfor, on searo-gimmas, / on ead, on æht, on eorcan-stan" 22 and is granted gold and rings. ${ }^{23}$ These material joys go hand in hand with the joys of the feast, the pleasures of wine and music, the company of a woman, or any other worulde bybt ("hope" or "joy in the world," Seafarer 45). Among warriors, valiant deeds usually entail boasting about them. However, the Wanderer as well as the Seafarer recognise the transience of reputation; the former even warns against boasting and recommends patience, prudence, and wisdom in lines 65-72. In order to become "wita," "wis" or "snottor" ("a wise person" or "wise," W anderer 64-65, 111), a man needs to identify the transience of earthly, superficial goods and contain his emotions. They are mere outbursts of momentary impressions and must never be revealed too hastily. Being "mod-wlonc," "deor [in his dædum]," and "geogup" ("proud," "brave [in his deeds; see also 76]," and "youth," Seafarer 39-41) constitute additional qualities and values regarded as desirable on earth. Only the few individuals outside of heroic society, such as the exiled protagonists, are aware of their lane nature. Kingship, presented in the fourth and fifth stanzas of Deor, can be classed with earthly transient goods insofar as Đeodric's and Eormanric's reigns - and with them, their reputation as Gothic kings-lasted for restricted periods of time. This is equally applicable to Deor's own situation, as he had been honoured with serving as a people's poet, but lives in grief now, deprived of his life's vocation. Recalling Bede's image of the sparrow, time is uncertain, and, according to the Seafarer, uncertainty is also an issue where "adl oppe yldo oppe ecg-hete" ("a disease or age or hostile hate," Seafarer 70) are involved. Disease and hate can end one's life; as the speaker explicitly visualises in lines 89-96, the process of aging certainly does.

The transience of human and earthly joys is evident in all four elegies. ${ }^{24}$ The Wanderer mentions "gear-dagas" ("days of old," 44) and notices that "wyn eal gedreas" ("all joy has perished," 36) with the fact that "ponne eall pisse worulde wela weste stondeð." 25 Emphasising that there is "this world" insinuates that the speaker knows of other worlds consecutively replacing the present one. It parallels the Seafarer's perception, since to him, life is "dead ..., / læne on londe" ("dead ... transient on land," 65-66) and he overtly states: "ic gelyfe no / pæt him eorð-welan ece stondað.” 26 Both Seafarer and Wanderer are solitary characters. In contrast to the Seafarer, who chooses to experience separation from society, the

\footnotetext{
21 "Many mead halls full of human joys," Ruin 23; see also "sele-dreamas," "hall joys," Wanderer 34-36, 78-80, 93.

22 "Looked at treasure, at silver, on precious stones, on riches, on property, on jewels," Ruin 35-36.

23 Seafarer 44, 83, 97, 101; Wanderer 22, 32, 35, where gold is an element of gold-wine.

24 The poems both include "wyn" and "dream" (Wanderer 29, 36, 79; Seafarer 27, 45, 65, 80, 86).

25 "When all the riches of his world stand empty," 74.

26 "I do not believe that the wealth of earth lasts eternally," 66-67.
} 
latter's exile is not self-imposed since all his kinsmen and his lord have died and left him alone dwelling in nostalgia about the past. In the manner of the ubi sunt topos, which scholars have derived from Isidore of Seville's Synonyma, the Wanderer wonders where all the earthly things and people have gone. Isidore's astonishment "Dic ubi sunt reges? ubi principes? ubi imperatores? ubi locupletes rerum? ubi potentes saeculi? ubi diuites mundi? quasi umbra transierunt, uelut somnium euanuerunt" 27 was highly popular in Anglo-Saxon England and caught on in both poetry and prose (Fell 185, Orchard, "Not What It Was" 103, Sciacca 105, 138). Accordingly, the Wanderer eventually detects that "her bið feoh læne, her bið freond læne, / her bið mon læne, her bið mæg læne," 28 leaving the world an "idel" ("empty," 110) place..$^{29}$ This recognition accords with the refrain of Deor which declares "pæs ofereode; pisses swa mæg," 30 affirming that there is an end to every kind of hardship and thus providing a consoling conclusion for sufferers. All three speakers realise at some point that earthly goods and gifts "are merely transitory delights" and opposed to the "true and everlasting ... joys of the Lord" (Klein 120). In particular, the second half of The Seafarer directs towards Christian ideas and advocates for readiness for God's judgement.

No earthly splendour lasts forever, and neither does human misery. Either other people, fate, or the mighty Lord are presented as the causes for sudden changes in life and suffering. Deor's situation resembles Welund's confinement, and both Beadohild and Mrðhild have fallen victim to male revenge and passion. Another case in point is a people's suffering under the "grim cyning" ("cruel king," 23) Eormanric under whose rule even the warriors were "sorgum gebunden, / wean on wenum." 31 Similarly, the speaker addresses someone "sorgcearig" ("one oppressed with sorrow," Deor 28) who notices how the "witig Dryhten" ("wise Lord," 32) honours some and punishes others by inflicting misery on them. Here, the mighty Lord is responsible for the changes in the world and his will is unchangeable. Deor knows that God moves in mysterious ways. Bringing his fate into line with other individuals' misfortune and ultimately reminding himself of the fact that his suffering is just as transient as the divine gift of being the chosen poet gives him solace. Since God has a purpose for every human being, "suffering must have a purpose" as well (Fell 192).

In the case of The Wanderer, the reader is confronted with the hardship of solitude. Toswell stresses the "anthropomorphic connection of birds with individual Christians" as glossed psalters testify (9). Defining the "sparrow in Psalm 101.8 as

\footnotetext{
27 "Speak, where are the kings? Where the princes? Where the emperors? Where the wealthy ones of possessions? Where the powerful of this age? Where the rich men of this world? They have passed away like a shadow, they have vanished like a dream," Sciacca 106.

28 "Here money is transient, here friend is transient, here man is transient, here kinsman is transient," 108-09.

${ }^{29}$ See also the ubi sunt topos in The Wanderer $92-93$.

30 "That passed away; so may this," 7, 13, 17, 20, 27, 42.

31 "Bound with sorrows, in supposition of misery," 24-25.
} 
an anhoga" (9) immediately recalls the Wanderer's characterisation: the speaker, initially identified as an "an-haga" ("recluse" or "one dwelling alone," Wanderer 1), misses his kinsmen and friends; notably his lord was dear to him as he imagines himself embracing and kissing him (9-11, 20, 29-31, 34-43). Just as Bede's solitary sparrow has the pleasure of catching the feeling of warmth and safety, so has the Wanderer experienced the ephemeral pleasure to be of service to a generous "gold-friend." Furthermore, the Christian message, revealing itself at the end, lets the Wanderer appear as a Christian believer whose hope enables him to endure his exile. Keeping in mind that there is no friend left who could have conveyed comfort to him, the Wanderer travels winter-cearig ("depressed by winter" or "sad from age," 24) on the sea with a fert-loca freorig ("frozen soul enclosure," 33), matching both the ice-cold sea and the weather. Nostalgia and feelings of loss influence his mood and worry his heart. Nevertheless, he knows that a sorrowful emotion or thought "ne mæg ... wyrde wiðstondan"32 since "wyrd bið ful aræd" ("fate is fully resolute," 5). Fate does not alter its course for any human being but is controlled by God and hence serves as his instrument to order life on earth: "onwendeð wyrda gesceaft weoruld under heofonum." 33 Concerning its caprice, fate's nature resembles that of the Lord as Deor perceives it and appears as a force that is predestined. However, the Wanderer sees two superior forces operating. While fate is qualified as "mære" ("mighty," 100), God "ypde swa pisne eard-geard" ("thus destroyed this dwelling place," 85). This implies the motif of transience and equally establishes the world's contrast with the kingdom in heaven "pær us eal seo fæstnung stondeð" ("where for us all stability stands," The Wanderer 115) —a fortress without an earthly, decaying nature but one that ensures eternal safety and stability. Every Christian reader can certainly deduce hope from this conclusion. However, the theme of transience is not primarily a Christian idea. It already inheres, together with the focus on fate's power, in Scandinavian and Germanic poetry. ${ }^{34}$ In a way, these two motifs operate as links between the pagan poetic tradition and Christian ideas (Gordon 1, 4, 7-8, 13).

The Seafarer's fate resembles the Wanderer's suffering. He laments over his bitre breost-cearu ("bitter grief of the heart," Seafarer 4) and "hu ic geswinc-dagum / earfoð-hwile oft prowade," 35 and he is harrowed by the terrible cold. Corresponding to this, Klein noticed that "[i]n male-voiced elegies, the natural world appears as a series of threatening forces that register human frailty in the face of social and spiritual alienation" (118). Protected neither by society nor "God's love, the male exile must acknowledge his own vulnerability as a human and bodily being" in-

\footnotetext{
32 "Cannot ... withstand fate," 15.

33 "The decree of fate changes the world under the heavens," 107.

34 The Hávamál, an Old Icelandic eddic poem, is often quoted since it resembles the Old English phrase: "Deyr fé, deyja frændr, deyr sjálfr it sama"—_Cattle die, kin die, one’s self dies." The poetic lines as well as their translation are taken from Fell p. 183.

35 "How I, in days of toil, have often suffered a time of hardship," 2-3.
} 
stead (118). Feeling earm-cearig ("miserable and sad," 14) with a fea-sceaftig ferd ("poor soul," 26), the Seafarer realises that the ones who have never left the safe ground ashore and enjoyed their lives cannot empathise with him in his misery. He is solitary in every aspect; his modes lust ("desire of the mind," 36) and his longung ("longing," 47) for isolation and a spiritual experience make him an exceptional character in his world. There, both God and fate determine the course of events. The "ece Dryhten" ("eternal Lord," 124) has a purpose for everyone in his overarching plan and as "the author of linear time, is seen in his role as the initial creator of mankind and the final destroyer of it" (Bately 13). Transient earth and eternal heaven are juxtaposed in opposition by referring to a fage ("doomed one," Seafarer 71) who awaits "Godes egsan" ("God's terror," 101) on the Day of Judgement for the "sawle pe bip synna ful" ("the soul that is full of sins," 100) and to "pa ecan eadignesse / pær is lif gelong in lufan Dryhtnes, / hyht in heofonum." 36 The following statement assures the insignificance of mankind compared to the powers of God and fate: "wyrd bip swipre, / meotud meahtigra ponne ænges monnes gehygd." ${ }^{37}$ Heaven is the eternal kingdom and the true stable home where one receives consolation from God. Through his absence from The Ruin, this poem distinguishes itself from the other three. Wyrd seo swipe ("strong fate," Ruin 24; see also 1) is the only almighty power that alters the course of events, takes lives, and destroys buildings. Fate changed the once wondrous city and transformed it into a desolate, dead place without any joy or splendour. Earthly misery is seen from a more general perspective as well. There is no mention of individual characters but we learn that age and death prevailed in the forms of slaughter, war, and "wol-dagas" ("days of pestilence," Ruin 25), having killed valiant men and "hund cnea / wer-peoda" ("a hundred generations of people," 8-9).

If earthly goods and gifts are not certain or granted forever, one thing is certain: God and fate cause changes and determine human destiny. Whereas the human soul can expect an eternal life in the safe haven of the heavenly kingdom, the world is solely deemed a transient interstation. Lives, joys, treasures, cities, dynasties, and ages will depart at some point and clear the space for other times. The line of thought in The Seafarer resembles the one in The Wanderer: the larger part of the poems stresses the elapsing of time on earth, but the eternity of God's heaven and its location outside of any temporal measurement become evident at the end. All elegies revisit the Boethian concept as presented in The Consolation of Philosophy. Since they fade and leave sheer misery behind, worldly goods are classified as the wicked or "human" goods and contrast with the truly desirable goods

\footnotetext{
36 "The eternal happiness, where life comes from the love of the Lord, hope in the heavens," 120-22.

37 "Fate is stronger, the Lord mightier than the thought of any man," 115-16.
} 
of divine virtues whose climax is ultimate happiness (Boethius 42-51). ${ }^{38}$ In this sense, exile and suffering can technically be regarded as desirable hardships since they highlight the importance of higher values and virtues that really enrich earthly life and make the human being appreciate it.

\section{Conclusion}

Having approached four Old English elegies against the background of transience as their pivotal theme and its different images, one conclusion immediately presents itself: human life as conceived and depicted in Old English poetry does not only have a transient nature but it is insignificant compared to wyrd seo swipe and the ece Drybten. This can be seen in the various ways The Wanderer, The Seafarer, Deor, and The Ruin approach and depict earthly life. Seasons change while the elemental forces unfold or withdraw their power. They emerge as wintry cold, stormy seas, and icy tempests of hail or snow, occasionally involving a threatening darkness. Just like the natural environment can darken, so can both the heart and the mind of the seafaring exile. In its function as their burial place, the dark earth holds the bodies of warriors and architects in its metaphorical tight grip. The ground is a grave as well as a force that devours whole cities. It has "swallowed" the ancient enta geweor in The Ruin and has left a desolate place behind. On top of this, winter and darkness represent sinfulness and evil that reside on earth and stand in opposition to the light and stability of heaven. Once, walls, halls, and buildings had been full of life and human joys, the city's appearance had been bright and splendid before wyrd destroyed and deprived it of the colours of life. These images evoke the Christian view of apocalypse which Greenfield sees appear particularly in The Seafarer (210). The image of ruins as well as the Seafarer's and Wanderer's perceptions that earthly gifts and goods are lane and should be treated with caution serve as warnings for themselves and the audience. Life is short and transient and resembles the swift flight of a sparrow through a warm hall in winter. All stability and eternity rest in God and the heavenly realm. The human soul, in search for this safe haven, travels from earth to heaven just as both Seafarer and Wanderer voyage on the open sea in order to find divine comfort. The contrast between earthly transience and heavenly eternity prevails in the four elegies to a greater or lesser extent. Transience appears as a tool of prudence in order to remind the human audience of how momentary gifts, honours, and even human relationships can be. Nothing lasts forever and therefore, as the speaker of The Wanderer recommends, one must be patient, moderate, and prudent.

\footnotetext{
38 To be more precise, the wicked goods are riches, reputation, power, fame, and (bodily) pleasures, while the true goods are not of a material nature. Self-sufficiency, renown, respect, joy, and power equate happiness with goodness. God is the final destination.
} 
Statements and boasts are not to be made too hastily but one should attain wisdom beforehand.

On earth, cold atmospheres set the background for the elegies and already imply their topics. Wintry weather and dark surroundings create images of destruction, desolation, decay, and death. Ruinous architecture visualises transience, which is mirrored in the fates of individual characters. In particular, the Wanderer, the Seafarer, and Welund experience their personal hardships in a frosty-cold exile. Their exiles, whether or not self-imposed, imply isolation and remoteness from any companions. In contrast to Welund, the Seafarer and the Wanderer follow a common goal: they strive for consolation from the heavenly Father in his eternal home. The situation is different with Deor. The mighty Lord has deprived him of his vocation in life and replaced him with the new poet of his people. He has lost his aim which allows for the reasonable argumentation that at closer inspection, aimlessness is far worse than exile, since Wanderer and Seafarer gain something out of their spiritual voyages.

Fell's harsh judgement that the elegies do not have a lot in common other than central themes (180) definitely needs reconsideration, which leads us, at last, right back to their common source: the Exeter Book unites them and has kept them safe until today. Indeed, the elegies differ from each other in many ways and every single one undoubtedly — and wonderfully — speaks for itself. Nevertheless, their common features transcend the main themes. Not only the motif of transience runs like a golden thread through the poems but also does the depiction of cold and stormy landscapes, decay, death, lost treasures, past joys, suffering, and human solitude. Everyone reading and appreciating the Old English elegies is invited to remember the wise words of the Wanderer: "swa pes middan-geard / ealra dogra gehwam dreoseð ond feallep." 39

\section{Works Cited}

Anderson, Earl R. "The Uncarpentered World of Old English Poetry." AngloSaxon England 20 (1991): 65-80.

Bately, Janet. "Time and the Passing of Time in The Wanderer and Related OE Texts." Essays \& Studies 37 (1984): 1-15.

Bjork, Robert E., ed. and trans. Old English Shorter Poems. Volume II: Wisdom and Lyric. Cambridge, MA: Harvard UP, 2014.

Bosworth, Joseph. An Anglo-Saxon Dictionary. Revised and enlarged by T. Northcote Toller. Oxford: Oxford UP, 1898.

Colgrave, B. and and R.A.B. Mynors, eds. Bede: The Ecclesiastical History of the English People. Oxford: Clarendon, 1969.

39 "So this middle earth perishes and falls each day," 62-63. 
Fell, Christine. "Perceptions of Transience." The Cambridge Companion to Old English Literature. Eds. Malcolm Godden and Michael Lapidge. 2nd ed. Cambridge: Cambridge UP, 2013. 180-97.

Howlett, David R., ed. Dictionary of Medieval Latin from British Sources. 17 vols. London: Oxford UP, 1975-2013.

Gordon, Ida L. "Traditional Themes in The Wanderer and The Seafarer." The Review of English Studies 5 (1954): 1-13.

Greenfield, Stanley B. "Sylf, Seasons, Structure and Genre in The Seafarer." AngloSaxon England 9 (1980): 199-211.

Holton, Frederick S. "Old English Sea Imagery and the Interpretation of The Seafarer." The Yearbook of English Studies 12 (1982): 208-17.

Irvine, Susan. "Speaking One's Mind in The Wanderer." Inside Old English: Essays in Honour of Bruce Mitchell. Ed. John Walmsley. Malden: Blackwell, 2006. 117-33.

Klein, Stacy S. "Gender and the Nature of Exile in Old English Elegies." A Place to Believe in: Locating Medieval Landscapes. Eds. Clare A. Lees and Gillian R. Overing. University Park, PA: Pennsylvania State UP, 2006. 113-31.

Klinck, Anne L. The Old English Elegies: A Critical Edition and Genre Study. Montreal et al.: McGill-Queen's UP, 1992.

Orchard, Andy. "Not What It Was: The World of Old English Elegy." The Oxford Handbook of the Elegy. Ed. Karen Weisman. Oxford: Oxford UP, 2010. 101-17.

-. "Reconstructing The Ruin." Intertexts: Studies in Anglo-Saxon Culture Presented to Paul E. Szarmach. Eds. Virginia Blanton and Helene Scheck. Tempe, AZ: ACMRS, 2008. 45-68.

Pheifer, J. D. "The Seafarer 53-55." The Review of English Studies 16 (1965): 282-84.

Sciacca, Claudia di. Finding the Right Words: Isidore's Synonyma in Anglo-Saxon England. Toronto: U of Toronto P, 2008.

Toswell, M.J. "Bede's Sparrow and the Psalter in Anglo-Saxon England." ANQ: A Quarterly Journal of Short Articles, Notes and Reviews 13 (2000): 7-12.

Walsh, P. G., trans. and intr. Boethius. The Consolation of Philosophy. New York: Oxford UP, 1999. 